\title{
Discourse Markers to College English Listening Proficiency: An Empirical Study of Explicit and Implicit Instruction
}

\author{
Jian-Feng Zhang ${ }^{1}$ \\ ${ }^{1}$ College of Humanities and Foreign Languages, Xi' an University of Science and Technology, China \\ Correspondence: Jian-Feng Zhang, College of Humanities and Foreign Languages, Xi'an University of \\ Science and Technology, Lintong District, Xi'an city, Shaanxi 710600, China. Tel: 86-180-669-771-27. \\ E-mail: zhangjianfeng091024@126.com
}

Received: November 9, 2013 Accepted: December 15, 2013 Online Published: February 22, 2014

doi:10.5539/ells.v4n1p48 URL: http://dx.doi.org/10.5539/ells.v4n1p48

\begin{abstract}
Discourse markers, which are series of words, phrases or expressions, are able to state clearly the structure of discourse, to give the hearer a cue for the context, and to express clearly the concrete speech acts. Listening instruction that is based on the theory of discourse markers can significantly enhance college students' listening proficiency; therefore, it is significant and necessary to study the relationship between explicit and implicit instruction in discourse markers and listening proficiency in English as Foreign Language environment. Based on the elaborate experimental design and accurate statistical analysis, the conclusion can be drawn that in the short run, explicit instruction in discourse markers can improve listening proficiency immediately in contrast with the effect of implicit instruction that is not significant, but in the long term, however, the differences between the explicit and the implicit disappear and the implicit can improve listening proficiency as well as teaching performance apparently.
\end{abstract}

Keywords: discourse markers, explicit instruction, implicit instruction, listening proficiency

\section{Introduction}

Discourse markers (henceforth DMs) are important lexical expressions in pragmatics. DMs are able to state clearly the structure of discourse, to give the hearer a cue for the context, and to express clearly the concrete speech acts (Wilson, 2000). The researches of discourse markers have grown rapidly in applied linguistics and pragmatics in the decade (Aijmer, 2002). A wealth of studies that have tried to state or definite the meaning or functions of DMs indicates that listening instruction which is based on the theory of discourse markers can significantly enhance college students' listening proficiency in English as Foreign Language environment (Zhang, 2012).

A number of theoretical and empirical studies as well as sufficient examined evidence in pragmatics illustrate that instructions are capable of aiding the grasp of pragmatic competence and of having a positive influence on second language acquisition. With the development of pedagogical research, numerous evidence shows that a range of features of second language pragmatics can be taught through various pedagogies, so nowadays, the disputes in pragmatics are focused on explicit instruction or implicit instruction (Rose, 2005). Therefore, in this paper, the relationship between explicit and implicit instruction in DMs and listening proficiency in EFL environment will be examined in order to improve the effectiveness and efficiency of college English listening instruction in China.

\section{Literature Review}

\subsection{Discourse Markers and Listening Comprehension}

The term of discourse markers has been defined by scholars for various research fields. Schiffrin defines DMs as "sequentially dependent elements which bracket units of talk" (Schiffrin, 1987). Fraser defines a $\mathrm{DM}$ as a linguistic expression. He believes that the discourse marker has a core meaning which can be enriched by the context and at the same time, DM can highlight the relationship between the foregoing utterance and the rear the speakers tend to express (Fraser, 1999). Based on the Relevance Theory, Blakemore calls DMs as "discourse connectives": "expressions that constrain the interpretation of the utterances which contain them by virtue of the inferential connections they express" (Blakemore, 1987). 
Therefore, the DMs can be regarded as some expressions that are able to limit the hearer's understanding because DMs clearly show the speaker's intention and the utilization of DMs is an important way to make contextual assumptions which help hearers to interpret speakers' utterance deeply and completely.

According to these definitions which have mentioned above, some generalizations of DMs should be made: generally speaking, DMs are a series of words, phrases or expressions that come from classes of conjunctions, adverbials, prepositional phrases and other short sentences. They are usually utilized to show the speaker's communicative purposes and to make the communication more fluent and to become easy to be understood. On the other hand, MDs do not contribute to the meaning of the communication. In other words, if these DMs are removed from the sentences, the semantic relationship between the elements they connect will keep the same; what's more, without the DMs, the grammar of the utterance is still correct. (Zhang, 2012)

Listening is a kind of complicated skill and not easy to investigate. Researches in listening still exist in the exploratory stage. At the moment, although many theoretical and empirical studies have been done, yet there is a lack of consensus about the definition of listening comprehension. Being a very important skill in interactive communication, listening is also the most vital "input" medium in learning a foreign language. Krashen (1982) brings forward the "input hypothesis" and "comprehensible input" which have put emphasis on the importance and significance of listening comprehension. Krashen illustrates that the comprehensible input plays a vital role in second language acquisition and the comprehension-before-production approach is able to enhance the language acquisition especially in the early stages.

On the relationship between DMs and listening comprehension, Chaudron and Richard (1986) analyze the impact of DMs on the comprehension of academic lecture in English as native language, and they draw a conclusion that DMs can improve listening comprehension. They have defined two kinds of discourse signals in a lecture: macro-markers and micro-markers. The former (e.g., Today, what we are going to talk about is...) can indicate the whole structure of a lecture by stressing the major ideas of the lecture and showing the sequence or structure of the information. The latter (e.g., but, and, moreover, therefore...) signals the links among sentences and can function as fillers in the lecture.

Hron et al. contrast two versions of listening script with and without discourse markers through empirical study in English language environment. They find that listeners who have heard the listening materials with DMs outperform significantly than those who have heard the version without English DMs. (Rubin, 1994)

Thompson (2003) gives special attention to the roles of DMs in the academic talks. He concludes that the utilization of DMs in authentic lectures in college can help undergraduates form so-called "mental maps" to understand the contents in the whole lecture, especially in talks of EAP (English for Academic Purposes).

\subsection{Explicit Instruction versus Implicit Instruction}

According to Ellis (1994), explicit instruction is characterized by a series of supports or scaffolds and instructors guide learners through clear explanations and demonstrations until independent mastery has been achieved, while implicit instruction is usually defined as acquisition of knowledge by a process which occurs naturally, simply and without conscious operation. The results of learning material should be internalized without having learners' attention focused on it. The main distinction of these two pedagogies is that learners are consciously aware of the potential roles of language input.

In recent years, the different effects of explicit and implicit instruction have received a lot of attentions. Numerous studies provide the teachability of pragmatic features and such studies usually adopt explicit-implicit-instructional contrast. Wildner-Basset (1994) utilizes a pretest-posttest design to show that a particular area of pragmatics is teachable. Bouton compares explicit instruction with implicit instruction in pragmatics and finds that learners in an explicit group outperform those in an implicit group (Bouton, 1994). Kubota (1995) replicates Bouton's study but he draws an opposite conclusion in Japanese EFL environment.

At present, there are only a few empirical studies in Chinese EFL environment; therefore, it is necessary to utilize empirical study to analyse the relationship between explicit and implicit instruction in DMs and listening proficiency of Chinese college English learners. 


\section{Research Methodology}

\subsection{Subjects}

The subjects of this research are two classes (one hundred and twenty six freshmen) from Xi'an University of Science and Technology. Class 1 is carried out the explicit instruction and Class 2 accepts the implicit instruction of DMs in listening. Table 1 shows the basic information of subjects.

Table 1. Basic information of subjects

\begin{tabular}{lcccc}
\hline & $\mathrm{N}$ & Male & Female & Average age \\
\hline Class 1 & 63 & 42 & 21 & 20.7 \\
Class 2 & 63 & 50 & 13 & 19.3 \\
Total & 126 & 92 & 34 & 20.0 \\
\hline
\end{tabular}

In the experiment, the instruction is independent variable and the grades of subjects are dependent variables. Moreover, these two classes belong to parallel classes, having the same English instructors, listening materials, listening environment and the identical listening class time (4 classes per week).

Besides, the reason to choose freshmen is that they just come into college, so they should be interested in English listening and active in listening class. In addition, because they don't have the heavy burden for CET4 (College English Test 4), their learning should be less utilitarianism; furthermore, they are 20 years old and have learned English for at least six years, so it can guarantee that they are able to receive the training of listening strategies, which can ensure the reliability of instruction.

\subsection{Procedures}

The research is divided into 2 stages and lasts 33 weeks, which begins in September, 2012 and ends in July, 2013. The first stage includes 16 weeks from 9, 2012 to 1, 2013, and the second stage lasts 17 weeks from 3 , 2013 to 7, 2013. In the beginning of the stage 1, a pre-test is arranged to test the similarity of listening proficiency between Class 1 and Class 2; at the end of stage 1, subjects are tested by the post-test; when stage 2 ends, there is a delayed post-test for students.

In explicit instruction (Class 1), the researcher has utilized multimedia technology to instruct and train the definitions, classifications, functions and usages of DMs in listening class. According to Blakemore (Blakemore, 1992), in this study, DMs are divides into four types: introducing contextual implications, such as therefore, thus, so, accordingly, as a consequence, in this case, as a result; strengthening existing assumptions, such as and, you see, after all, since, because, you know, also, what is more, moreover, furthermore, in addition, indeed; introducing denials, such as however, nevertheless, though, but, yet, on the other hand, conversely, still; specifying the roles of utterance, such as first, finally, return to my point, well, either, too, also, by the way, anyway, speaking of.

In implicit instruction (Class 2), the instructor has made use of heuristic methods to train students' pragmatic competence and to aids them in acquiring the knowledge of DMs in listening consciously.

\subsection{Instruments}

All subjects in the Class 1 and the Class 2 are tested by pre-test $(\alpha=0.8293)$, post-test $(\alpha=0.8293)$ and delayed post-test $(\alpha=0.8698)$ during the 33 weeks. The questions of these three listening tests are elaborately chosen from the Question Bank in College of Humanities and Foreign Languages of Xi'an University of Science and Technology, which have high reliability and validity. The tests of Class 1 and Class 2 are carried out in the two identical listening labs at the same time. After each test, all papers are collected and sealed. Then an instructor corrects these papers according to the standard keys, which can avoid the subjective factors affecting the results of tests.

\section{Results}

\subsection{Pre-Test and Post-Test}

In order to ensure there is no significant distinction in listening proficiency between the two classes, a pre-test is arranged before the different instructions carried out. The total score of pre-test is 35 , which will be analyzed by SPSS 15.0. The results are showed in Table 2 . 
Table 2. The independent samples T-test of pre-test

\begin{tabular}{cccccccc}
\hline & $\mathrm{N}$ & $\mathrm{M} \pm \mathrm{SD}$ & $\mathrm{F}$ & Sig. & $\mathrm{t}$ & df & $\begin{array}{c}\text { Sig. } \\
(2 \text {-tailed })\end{array}$ \\
\hline Class 1 & 63 & $19.06 \pm 6.05$ & .28 & .60 & .35 & 124 & .73 \\
Class 2 & 63 & $18.70 \pm 5.75$ & & & & \\
\hline
\end{tabular}

In pre-test, the mean of Class 1 is 19.06 and Class 2 is 18.70 , and they are only over half of 35 . In the independent samples $\mathrm{T}$-test, $\mathrm{F}=0.28, \mathrm{p}=0.60$, equal variances are assumed. At the same time, $\mathrm{t}=0.35, \mathrm{df}=124$, and $p=0.73>0.05$, there is no statistical significance, which means there is no significant difference in the achievements between the Class 1 and Class 2. In other words, the learners in these two classes are completely homogenous in terms of their college English listening proficiency before the different instructions; therefore, the two classes can be compared to find out the differences after the instructions.

After 16-week instructions, the post-test is hold to test whether the listening proficiency improve or not. Just like the pre-test, the total score in post-test is still 35. The detailed results are showed in Table 3.

Table 3. The independent samples T-test of post-test

\begin{tabular}{cccccccc}
\hline & $\mathrm{N}$ & $\mathrm{M} \pm \mathrm{SD}$ & $\mathrm{F}$ & Sig. & $\mathrm{t}$ & df & $\begin{array}{c}\text { Sig. } \\
(2 \text {-tailed })\end{array}$ \\
\hline Class 1 & 63 & $21.45 \pm 3.66$ & 8.16 & .01 & 3.61 & 124 & .00 \\
Class 2 & 63 & $18.60 \pm 5.10$ & & & & \\
\hline
\end{tabular}

According to the post-test, the mean of Class 1 is 21.45 , which has passed ( $60 \%$ of the total score); while the mean of Class 2 is 18.60, which is lower than the one in pre-test. In the T-test for Equality of Means, we find $\mathrm{F}=8.16$ and $\mathrm{p}=0.01$, so equal variances are assumed. Meanwhile, $\mathrm{t}=3.61$ and $\mathrm{p}=0.00<0.05$, statistical significance exists, which means the difference between the Class 1 and the Class 2 is quite obvious after 16-week instructions.

The results of the pre-test and post-test indicate that the performance of the explicit instruction in DMs is really better than the implicit instruction in listening comprehension after the first instructional stage; therefore, it proves that the application of explicit instruction of DMs in college English listening instruction should effectively enhance Chinese students' listening proficiency.

\subsection{Delayed Post-Test}

After 17-week listening instructions and at the end of stage 2, the delayed post-test is arranged. Like the pre-test and post-test, the total score is 35 as well. The results of delayed post-test are shown in Table 4.

Table 4. The independent samples T-test of delayed post-test

\begin{tabular}{cccccccc}
\hline & $\mathrm{N}$ & $\mathrm{M} \pm \mathrm{SD}$ & $\mathrm{F}$ & Sig. & $\mathrm{t}$ & df & $\begin{array}{c}\text { Sig. } \\
(2 \text {-tailed) }\end{array}$ \\
\hline Class 1 & 63 & $22.09 \pm 4.08$ & .56 & .46 & .85 & 124 & .40 \\
Class 2 & 63 & $21.44 \pm 4.53$ & & & & \\
\hline
\end{tabular}

In delayed post-test, the implicit instruction (Class 2) has made great progress, which is higher than pre-test and post-test. Therefore, according to the independent samples T-test, under the homogeneity of variance, the value of $p$ is 0.40 and it is much higher than 0.05 . The data indicate that there is no statistical significance between the two classes in the delayed post-test. At that time, the differences between Class 1 and Class 2 disappear and their listening proficiency is homogenous again after 33-week instructions. 


\subsection{Further Investigation}

In these three tests, there is a phenomenon that should be concerned: comparing with the pre-test, the mean of implicit instruction in DMs (Class 2) decreases in the post-test, but in the delayed post-test, it increases dramatically. Therefore, the differences with each class are compared by the paired samples T-test that can investigate whether significant intra-class pre-post differences exist. The details are shown in Table 5.

Table 5. Paired sample test

\begin{tabular}{ccccc}
\hline & $\mathrm{M} \pm \mathrm{SD}$ & $\mathrm{t}$ & $\mathrm{df}$ & Sig. (2-tailed) \\
\hline Post 1-Pre 1 & $2.39 \pm 4.00$ & 4.73 & 62 & .00 \\
Delayed 1-Post 1 & $.64 \pm 2.40$ & 1.23 & 62 & .06 \\
Delayed 1-Pre 1 & $3.03 \pm 4.48$ & 5.37 & 62 & .00 \\
Post 2-Pre 2 & $-.10 \pm 2.07$ & 2.07 & 62 & .70 \\
Delayed 2-Post 2 & $2.84 \pm 3.24$ & 6.96 & 62 & .00 \\
Delayed 2-Pre 2 & $2.74 \pm 3.73$ & 5.82 & 62 & .00
\end{tabular}

Note: Pre 1=pre-test of Class 1, Post 1=post-test of Class 1, Delayed 1=delayed post-test of Class 1, Pre $2=$ pre-test of Class 2, Post 2=post-test of Class 2, Delayed 2=delayed post-test of Class 2.

Table 5 shows the differences between Class 1 and Class 2 in pre-test, post-test and delayed post-test. Obviously, the listening proficiency of explicit instruction in DMs (Class 1) has improved continuously. When the first stage ends, the performance has appeared significant difference, $p=0.00<0.05$. With the deepening of instruction, although the scores of post-test and delayed post-test don't have statistical difference, $\mathrm{p}=0.06>0.05$, yet in view of overall situation, the difference between delayed post-test and pre-test is still significant, $\mathrm{p}=0.00$. In short, the explicit instruction in DMs can improve the listening proficiency of learners in China and it helps to improve the performance of college English listening instruction as well.

On the other hand, in implicit instruction in DMs (Class 2), although the mean of post-test is lower than pre-test, they don't have significant difference, $p=0.07>0.05$. However, when post-test and delayed post-test as well as pre-test and delayed post-test are compared, the differences are significant, $p=0.00$. As a whole, the listening proficiency of learner is also improved. It shows that the implicit instruction in DMs needs longer cycles of instruction, so in the short run, the effect is not obvious, but in the long run, it also can significantly improve listening proficiency in EFL environment.

\section{Conclusion}

In this study, the research subjects are 126 Chinese college students, who are from Xi'an University of Science and Technology. An experiment has been hold by comparing the explicit and implicit instructions in discourse markers to enhance the English listening proficiency. The main goal of this research is to investigate the relationship between explicit and implicit instruction in DMs and listening proficiency in EFL environment.

In listening practice of ELF, the basic theories and functions should be instructed in listening comprehension. Learning about the definitions, classifications, functions and usages of DMs, learners will feel and grasp DMs gradually so that they will effectively understand the contents of listening materials.

By both qualitative and quantitative analyses, the theoretical model of DMs should be applied to classroom practices and it can make contribution to listening proficiency of learners; the college English listening instruction in China, compared with implicit instruction in DMs, the explicit can rapidly improve listening proficiency in a short run, but the effects of the implicit are not obvious; with the deepening of instruction, however, the differences between the explicit and the implicit will disappear. In the long run, the implicit instruction in DMs can improve listening proficiency and the effects will be more significant.

\section{Acknowledgement}

The research is financed by Scientific Research Program Funded by Shaanxi Provincial Education Department (Program No. 12JK0297). 


\section{References}

Aijmer, K. (2002). English Discourse Particles-Evidence from a Corpus. John Benjamins Publishing Company. http://dx.doi.org/10.1075/scl.10

Blakemore, D. (1987). Constraint on Relevance. Oxford: Blakewell.

Blakemore, D. (1992). Understanding Utterance. Oxford: Blakewell.

Bouton, L. (1994). Conversational implicature in the second language: Learned slowly when not deliberately taught. Journal of Pragmatics, 22(3), 157-167. http://dx.doi.org/10.1016/0378-2166(94)90065-5

Chaudron, C., \& Richards, J. C. (1996). The effect of discourse markers on the comprehension of lectures. Applied Linguistics, 7, 20-35. http://dx.doi.org/10.1093/applin/7.2.113

Ellis, N. C. (1994). Implicit and Explicit Learning of Language. London: Academic Press. http://dx.doi.org/10.1111/j.1467-1770.1994.tb01114.x

Fraser, B. (1999). What are discourse markers? Journal of Pragmatics, 31, 931-952. http://dx.doi.org/10.1016/S0378-2166(98)00101-5

Krashen, S. (1982). Principles and Practice in Second Language Acquisition. Oxford: Pergamon Press.

Kubota, M. (1995). Teachability of conversational implicature to Japanese EFL learners. IRLT Bulletin, 9 , 35-67.

Rose, K. R. (2005). On the effects of instruction in second language pragmatics. System, 33(3), 385-399. http://dx.doi.org/10.1016/j.system.2005.06.003

Rubin, J. (1994). A review of second language listening comprehension research. Modern Language Journal, 78(2), 199-221. http://dx.doi.org/10.2307/329010

Schiffrin, D. (1987). Discourse Markers. Cambridge: Cambridge University Press. http://dx.doi.org/10.1017/CBO9780511611841

Thompson, S. E. (2003). Text-structuring Metadiscourse, Intonation and the Signaling of Organization in Academic Lectures. Journal of English for Academic Purposes, 1, 5-20. http://dx.doi.org/10.1016/S1475-1585(02)00036-X

Wildner-Bassett, M. (1994). Intercultural pragmatics and proficiency: "Polite" noises for cultural appropriateness. International Review of Applied Linguistics, 32, 3-17. http://dx.doi.org/10.1515/iral.1994.32.1.3

Wilson, D. (2000). Relevance and Communication. Modern Foreign Language, 2, 200-217. http://dx.doi.org/10.1902/jop.2008.080172

Zhang, J. (2012). Discourse Markers in College English Listening Instruction: An Empirical Study of Chinese Learners. English Language Teaching, 3, 46-61. http://dx.doi.org/10.5539/elt.v5n3p46

\section{Copyrights}

Copyright for this article is retained by the author(s), with first publication rights granted to the journal.

This is an open-access article distributed under the terms and conditions of the Creative Commons Attribution license (http://creativecommons.org/licenses/by/3.0/). 